\title{
PHYSICOCHEMICAL AND ISOTOPIC CHARACTERIZATION OF FORMATION WATERS FROM OIL FIELDS IN THE SERGIPE BASIN, BRAZIL
}

\author{
Danilo R. Sá Teles ${ }^{1}$, Antônio Expedito G. de Azevedo ${ }^{1}$, Alexandre B. Costa ${ }^{1}$, \\ Maria R. Zucchi ${ }^{1}$ and Alexandre A. Ferreira ${ }^{2}$
}

\begin{abstract}
This paper presents a study of the physicochemical and isotopic characteristics of formation waters from the Castanhal, Siririzinho and Aguilhada fields in the Sergipe Basin, northeastern Brazil. In each of the samples, $\mathrm{pH}$, conductivity, concentration of dissolved inorganic carbon (DIC), $\delta^{18} 0, \delta^{2} \mathrm{H}$, and $\delta^{13} \mathrm{C}$ were measured. These measurements are used to identify isotopic similarities among waters from local aquifers, which can be used as a proxy for groundwater connectivity with formation water. Formation waters from the Castanhal and Siririzinho fields are enriched in deuterium, as evidenced by their $\delta^{2} \mathrm{H}$ values above the Global Meteoric Water Line (GMWL), which may be a result of significant isotopic exchange between water and $\mathrm{H}_{2} \mathrm{~S}$. These measurements are in accordance with the large enrichment in ${ }^{13} \mathrm{C}$ of $\mathrm{DIC}$ resulting from biodegradation, with the formation of methane depleted in ${ }^{13} \mathrm{C}$ and $\mathrm{CO}_{2}$ enriched in ${ }^{13} \mathrm{C}$. These results indicate interaction between formation water with rocks and other fluids.
\end{abstract}

Keywords: stable isotopes, dissolved inorganic carbon, biodegradation.

RESUMO. Este trabalho apresenta um estudo das características físico-químicas e isotópicas de águas de formação dos campos Castanhal, Siririzinho e Aguilhada, localizados na Bacia de Sergipe, nordeste do Brasil. Em cada uma das amostras foram medidos os parâmetros pH, condutividade elétrica, concentração de carbono inorgânico dissolvido (CID), $\delta^{18} 0, \delta^{2} \mathrm{H}$ e $\delta^{13} \mathrm{C}$. A partir dos resultados obtidos, foi possível identificar a similaridade isotópica com as águas de aquíferos locais, indicando conexão de água subterrânea com água de formação. As águas de formação dos campos Castanhal e Siririzinho apresentaram um enriquecimento em deutério, resultado da troca isotópica entre a água e $0 \mathrm{H}_{2} \mathrm{~S}$. Também foi verificado, um grande enriquecimento no $\delta^{13} \mathrm{C}$ do $\mathrm{CID}$, resultado dos processos de biodegradação com a formação de metano empobrecido em ${ }^{13} \mathrm{Ce} \mathrm{CO}_{2}$ enriquecido neste isótopo. Os resultados encontrados indicam interação entre a água de formação com as rochas e com outros fluidos.

Palavras-chave: isótopos estáveis, carbono inorgânico dissolvido, biodegradação.

\footnotetext{
${ }^{1}$ Universidade Federal da Bahia, Instituto de Física, Centro de Pesquisa em Geofísica e Geologia, Salvador, BA, Brazil. Phone: +55(71) 3283-6680/3283-6691 E-mails: danilosateles@yahoo.com.br; expedito@ufba.br; albarcos@gmail.com; mrzucchi@gmail.com

2 Petrobras, Research and Development Center (CENPES), Division of Geochemistry, Rua Horácio Macedo, 950, Illha do Fundão, 21941-915 Rio de Janeiro, RJ, Brazil. Phone: +55(21) 2162-7454 - E-mail: alexandrea@petrobras.com.br
} 


\section{INTRODUCTION}

Petroleum exploration involves the production of different fluids such as water, which in many fields is produced in high volumes. The characteristics and amount of this water depend on the geological composition and age of the reservoir rocks, time of productive life of the well, and method used for oil production. As the end of the useful life of a well is approached, the volume of water steadily increases and may exceed $90 \%$ of the fluid produced (Hunt, 1979; Ortiz, 2007).

Formation waters may originate from connate waters, ocean water, rainwater, groundwater, or even magmatic waters. At temperatures exceeding $80^{\circ} \mathrm{C}$, the water-rock interaction is intensified, resulting in isotopic exchange between the oxygen present in the water and minerals, resulting in ${ }^{18} 0$ enrichment in the water (Clayton et al., 1966; Grassi et al., 1996; Morad et al., 2003). Juan et al. (2009) studied oxygen and hydrogen isotopes from geothermal water in Chinese basins and observed a strong variation in isotopic compositions. They observed a growing enrichment in ${ }^{18} 0$ towards the center of the basin that was not observed in hydrogen isotopes. In rocks with low water saturations, they observed about $-40 \%$ deuterium excess (d).

According to Coplen \& Hanshaw (1973), compacted shales and clays can act as semi-permeable membranes to the passage of ions in aqueous solutions. This reverse-osmosis ultra-filtration process causes an increase in the total dissolved solids with depth and the enrichment of heavy isotopes of hydrogen and oxygen in the formation water.

At the same time, measurements of the concentration and $\delta^{13} \mathrm{C}$ of DIC in formation water provide important indications of the interaction of water with carbonate minerals, as well as the biogeochemical processes involved in the degradation of hydrocarbons. The isotopic effects associated with methanogenesis are among the most intense in nature. In this reaction, the degradation of lighter hydrocarbons by anaerobic microorganisms produces methane that is strongly depleted in ${ }^{13} \mathrm{C}$ and generates $\mathrm{CO}_{2}$ that is enriched in ${ }^{13} \mathrm{C}$ (Hunt, 1979; Head et al., 2003; Santos Neto, 2004; Jones et al., 2007).

The isotopic methodology used in this work was that used by Teles et al. (2010) to analyze formation waters from a mature field in the Recôncavo Basin. Samples were collected in a block without secondary recovery in production zones with depth ranging from 450 to $1500 \mathrm{~m}$, with hypersaline waters whose electrical conductivity varied from 80 to $140 \mathrm{mS} / \mathrm{cm}$. Enrichment in heavy isotopes of hydrogen and oxygen and the quantity of total dissolved salts at deeper levels were observed, which is compatible with ultra-filtration in shales and has no connection with meteoric water. Analysis of the concentration and inorganic carbon iso- tope value, performed after the publication of Teles et al. (2010), resulted in concentrations below $4 \mathrm{mM} / \mathrm{L}$ and $\delta^{13} \mathrm{C}_{\text {DIC }}$ values between -18 and $2 \%$, indicating localized interaction of formation water with carbonate minerals and a lack of $\mathrm{CO}_{2}$ generation by biodegradation.

In this study we analyzed the stable isotope composition of hydrogen, oxygen and carbon and the physicochemical parameters from different oil wells in the Sergipe basin to investigate the effects of hydrocarbon biodegradation on formation water and understand the water-rock interactions and the reactions involved. Evidence of fluid communication between formation water and local aquifers was also observed, as well as information for the monitoring of reservoirs for secondary recovery.

\section{STUDY AREA}

This study is focused on the following fields: Castanhal, which has low-saline formation waters and heavy oil; Siririzinho, which has more saline water; and Aguilhada, which has wells in carbonate rocks and below the salt level that produce hypersaline water. The study area is located in the vicinity of the Carmópolis field, as shown in Figure 1.

The upper part of the lithostratigraphic column for the area, shown in Figure 2, consists of the Barreiras (Pliocene), Riachuelo (Albian) and Muribeca (Aptian) formations, overlain discordantly on the basin. The Carmópolis Member comprises the main reservoir of the field, consisting of sandy conglomeratic deposits of alluvial fans interbedded with transgressive lacustrine shales (ANP, 2007). The Castanhal field and the main reservoirs of this basin are related to the oil system of the Muribeca formation Carmópolis Member (Milani \& Araújo, 2003). According to ANP (2007), the oil in this field has biodegraded and has a high viscosity (between 1000 and $9000 \mathrm{cP}$ ) and API gravity between $10^{\circ}$ and $18^{\circ}$.

Based on chromatography, isotope analyses and physicochemical properties, Babinski \& Santos (1987) constructed a model for the generation, migration, and accumulation of hydrocarbons in the Sergipe basin, identifying three types of oils: continental, marine-evaporitic, and mixed oils with different contributions of these end members. Oils generated in the Castanhal, Siririzinho, and Aguilhada fields were classified as marine-evaporitic and were generated by sediments from the Alagoas stage.

Carvalho (2005) investigated karst aquifers in the Riachuelo and Cotinguiba formations and the paleokarst associated with evaporites from the Muribeca formation, adjacent to our study area. Based on hydrogeological, hydrochemical and isotopic composition data for hydrogen and oxygen, he identified different flow environments, including the current meteoric recharge of waters in the Oiterinhos aquifer interpreted as paleo-waters. 


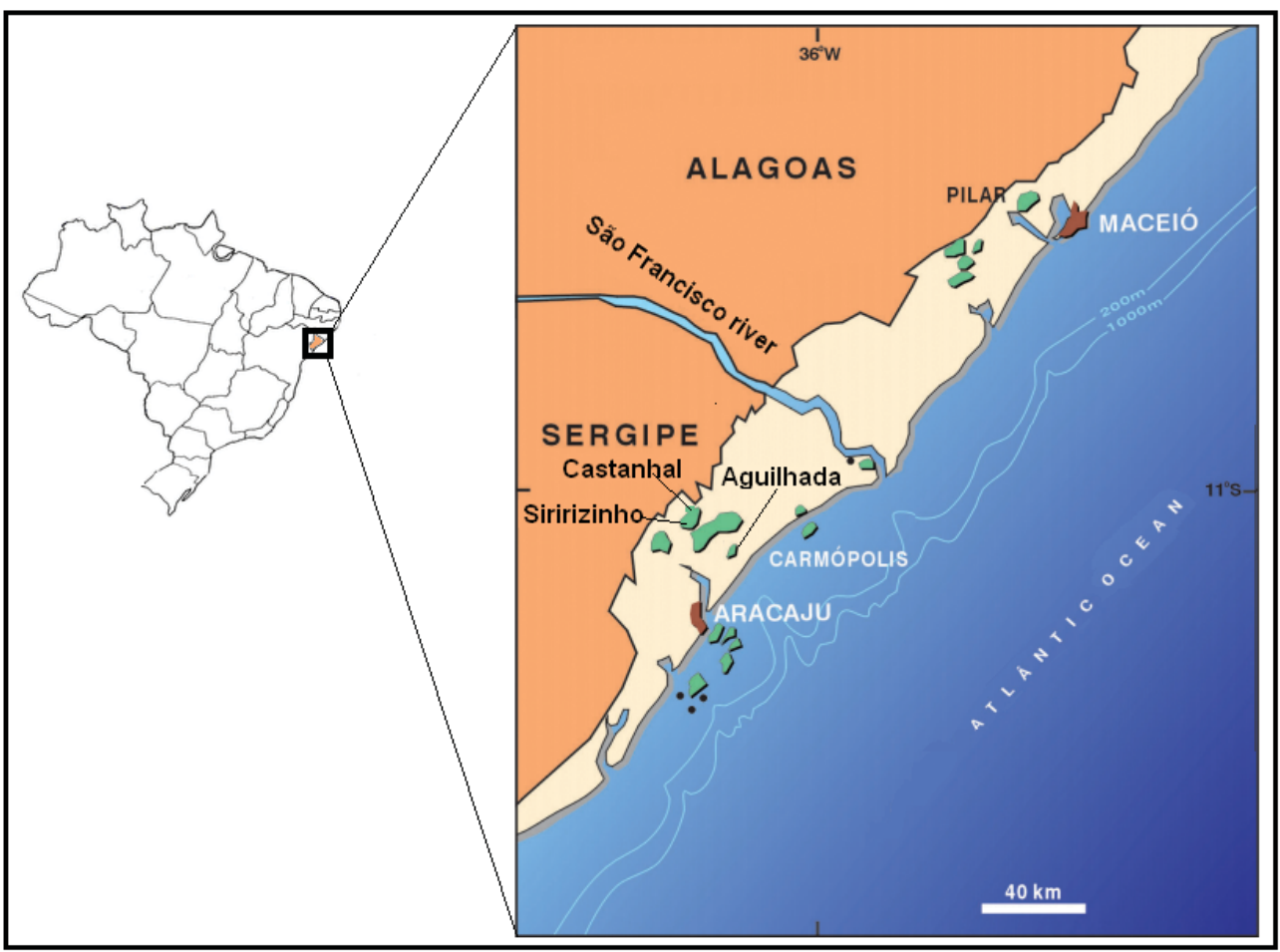

Figure 1 - Location of the sampled fields (modified from Milani \& Araújo, 2003).

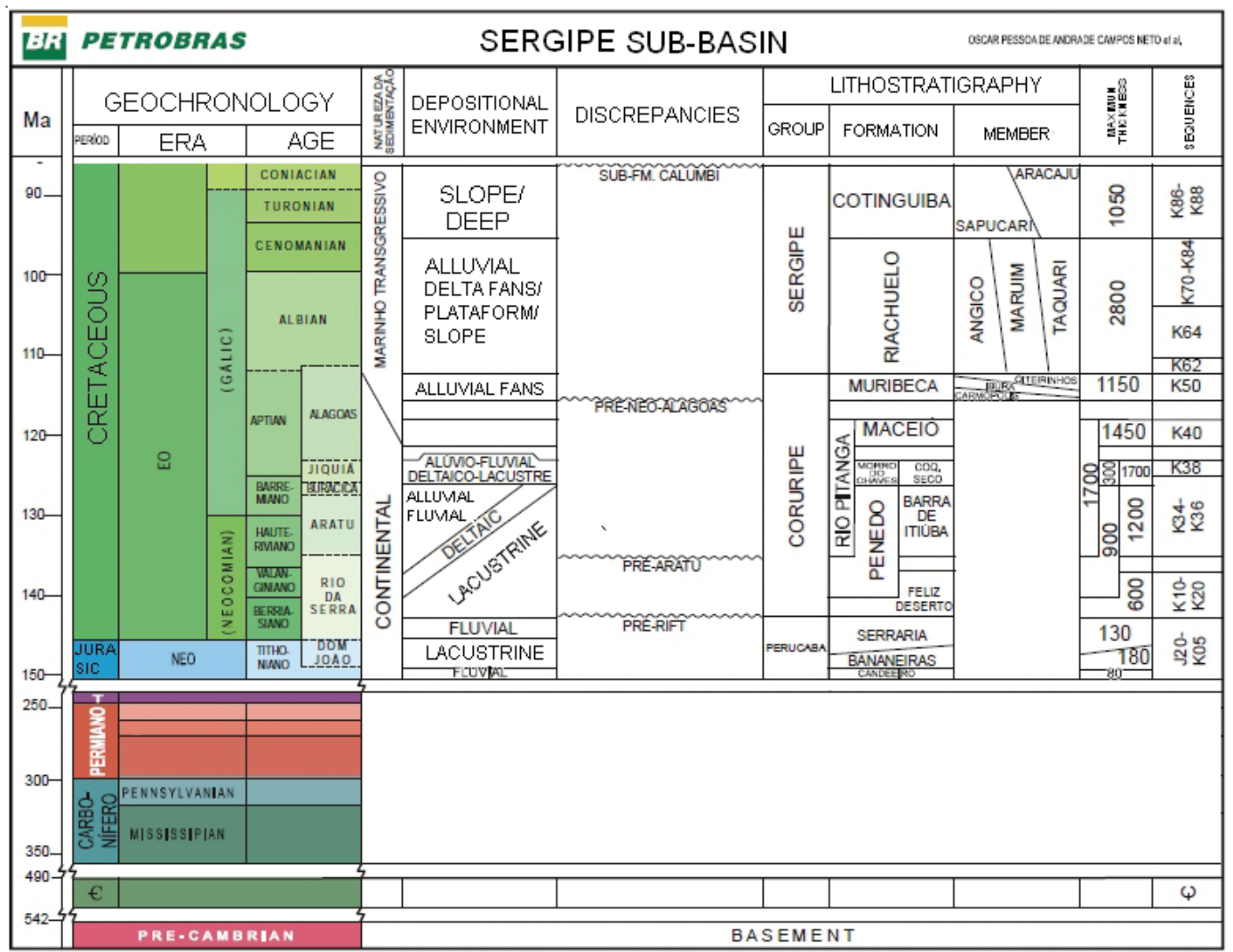

Figure 2 - Stratigraphic chart of the Sergipe sub-basin, modified from Campos Neto et al. (2007). 


\section{MATERIALS AND METHODS}

Samples of water produced in 16 wells were collected: 9 in the Castanhal field, 4 in the Siririzinho field and 3 in the Aguilhada field. As a control, one surface water sample was collected from the Prata spring in Japaratuba, Sergipe, Brazil, and the isotopic measurements on groundwater in the region reported by Carvalho (2005) were considered.

According to the protocol indicated by Lemay (2002), samples were collected at the wellhead in $5 \mathrm{~L}$ polyethylene bottles. After the separation of oil from the water, the samples were filtered through a $0.45 \mu \mathrm{m}$ Millipore filter. We measured $\mathrm{pH}$, oxidationreduction potential, electrical conductivity and DIC concentrations of the filtered samples and placed them in glass vials for further treatment and isotopic measurements. Hypersaline samples were submitted to cryogenic distillation according to Teles etal. (2010).

Isotope measurements were performed on the isotope-ratio mass spectrometry system at the Laboratory of Applied Nuclear Physics, Universidade Federal da Bahia (UFBA). Measurements of the isotopic ratio of hydrogen and oxygen were performed as described by Teles et al. (2010). Measurements of the isotope ratio of DIC were performed on the Gas-Bench ${ }^{\circledR}$ system coupled to a Delta Plus Thermo-Finnigan spectrometer. Isotopic values are expressed in the conventional delta notation, with data for hydrogen and oxygen relative to the Vienna SMOW standard and data for carbon relative to the Vienna PDB standard.

\section{RESULTS AND DISCUSSION}

The physicochemical and isotopic results are shown in Table 1 and discussed below.

The $\mathrm{pH}$ values of the whole set of water samples ranged from 5.4 to 9.3 (Table 1), indicating a slightly acidic to alkaline character. The three samples from the Aguilhada field (AG01, AG02, and AG03) showed the lowest pH values (6.9, 5.8, and 5.4, respectively) and were characterized as mildly acidic. The group formed by samples from the Castanhal and Siririzinho fields presented values between 7.7 and 9.3 , and were characterized as alkaline. Electrical conductivity measurements on well waters ranged from 1.7 to $204.9 \mathrm{mS} / \mathrm{cm}$. This parameter in Aguilhada field is significantly above those of seawater, which indicates that they are hypersaline. The Castanhal field presented the lowest electrical conductivities, between 1.7 and $21.4 \mathrm{mS} / \mathrm{cm}$. Electrical conductivities of 45.0 and $57.5 \mathrm{mS} / \mathrm{cm}$ were obtained for samples SZ01 and SZ03 (Siririzinho field), respectively (Table 1). These waters were characterized as brackish.

According to Carvalho (2005), the isotopic values of groundwater from the Maruim, Sapucari and Angico aquifers in this basin vary between -2 and $-1 \%$ for $\delta^{2} \mathrm{H}$ and between -1.9 and $-0.1 \%$ for $\delta^{18} 0$ (Table 2). The most negative values come from the Oiterinhos aquifer, which according to Carvalho (2005), indicate an origin related to the leaching of salts by meteoric water, accumulated from an old recharge, possibly in climatic conditions different from those of today. The $\delta^{18} 0$ and $\delta^{2} \mathrm{H}$ show enrichment in the heavy isotopes for lagoons. They are the highest average values for surface and meteoric water and are close to the global meteoric water line (GMWL). The samples CL04, CL05 and CL08 (Table 1) have isotopic compositions similar to the Sapucari and Angico aquifers, which may indicate interaction between these aquifers.

Figure 3 shows a diagram of $\delta^{2} \mathrm{H}$ versus $\delta^{18} 0$ for the samples from the studied fields. The data shown in Figure 3 and Table 1 indicate that, compared with samples from the other fields, samples from the Aguilhada field are depleted in deuterium, ${ }^{13} \mathrm{C}$ and DIC concentration. Samples from the Castanhal and Siririzinho fields have $\delta^{2} \mathrm{H}$ values between -5 and $3 \%$ and $\delta^{18} 0$ values between -2.9 and $-1.3 \%$. Deviations of these isotopic values from the GMWL are usually attributed to evaporation, isotopic exchange reactions and mixing.

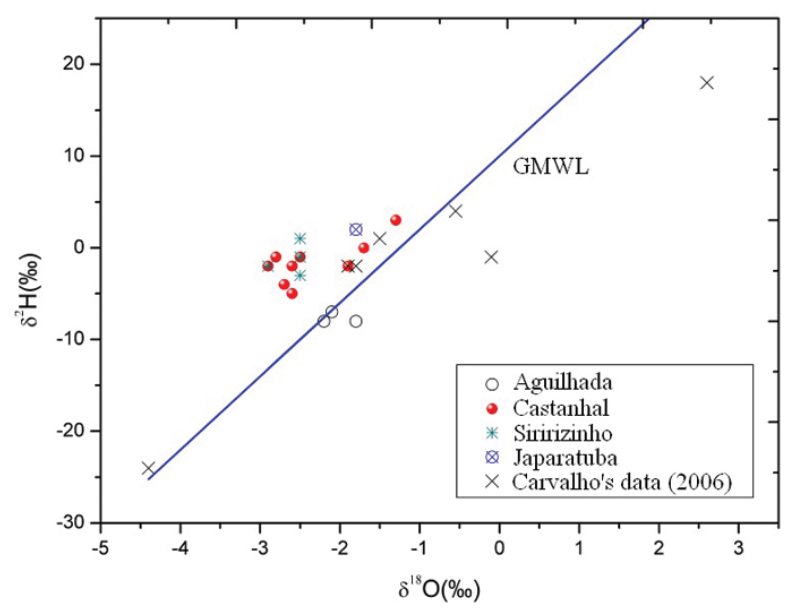

Figure 3 - Diagram of $\delta^{2} \mathrm{H}$ versus $\delta^{18} 0$ for the Aguilhada, Castanhal and Siririzinho fields, as well as surface and ground waters.

The $\delta^{2} \mathrm{H}$ values are influenced by several factors, including the mixing of waters from different origins, exchange with $\mathrm{H}_{2} \mathrm{~S}$, isotopic fractionation, and interaction with minerals containing hydrogen. The variation in $\delta^{18} 0$ among samples is relatively small compared with the variation in $\delta^{2} \mathrm{H}$, and more saline samples are concentrated below the GMWL.

The excess of deuterium, defined as $\mathrm{d}=\delta^{2} \mathrm{H}-8 \cdot \delta^{18} 0$, ranges from 6 to 21\%o (Table 1). The three samples collected from the Aguilhada field have the lowest values (between 6 and 10\%). For samples from the Castanhal and Siririzinho fields, 
Table 1 - Isotope and physicochemical results of waters from the Castanhal (CL), Siririzinho (SZ) and Aguilhada (AG) fields of the Sergipe basin.

\begin{tabular}{|c|c|c|c|c|c|c|c|c|}
\hline Well & $\mathrm{pH}$ & $\begin{array}{c}\text { ORP } \\
(\mathrm{mV})\end{array}$ & $\begin{array}{c}\mathrm{EC} \\
(\mathrm{mS} / \mathrm{cm})\end{array}$ & $\begin{array}{c}\delta^{18}(\%) \\
(\%)\end{array}$ & $\begin{array}{c}\delta^{2} \mathrm{H} \\
(\% 0)\end{array}$ & $\begin{array}{c}\mathrm{d} \\
(\%)\end{array}$ & $\begin{array}{c}\delta^{13} \mathrm{C} \\
(\%)\end{array}$ & $\begin{array}{c}\mathrm{DIC} \\
(\mathrm{mM} / \mathrm{L})\end{array}$ \\
\hline CL01 & 8.5 & -110 & 7.7 & -2.7 & -4 & 18 & 22.3 & 71 \\
CL02 & 8.1 & -431 & 6.6 & -2.6 & -5 & 16 & 6.4 & 43 \\
CL03 & 8.2 & -105 & 7.8 & -2.9 & -2 & 21 & 25.2 & 77 \\
CL04 & 8.5 & 7 & 3.1 & -1.7 & 0 & 14 & 21.3 & 28 \\
CL05 & 8.4 & -75 & 4.3 & -1.9 & -2 & 13 & 21.8 & 40 \\
CL016 & 7.9 & -110 & 5.3 & -2.6 & -2 & 19 & 20.0 & 51 \\
CL07 & 8.3 & -74 & 5.8 & -2.5 & -1 & 19 & 21.6 & 32 \\
CL08 & 8.8 & 1 & 1.7 & -1.3 & 3 & 13 & 14.0 & 1 \\
CL09 & 8.0 & -108 & 21.4 & -2.8 & -1 & 21 & 19.9 & 36 \\
SZ01 & 7.6 & 115 & 57.5 & -2.5 & -1 & 19 & 19.7 & 32 \\
SZ02 & 7.7 & -159 & 14.6 & -2.5 & 1 & 21 & 22.4 & 64 \\
SZ03 & 7.8 & 91 & 44.9 & -2.5 & -3 & 17 & 20.6 & 53 \\
SZ04 & 9.3 & -440 & 18.1 & -2.9 & -2 & 21 & 20.8 & 57 \\
AG01 & 6.9 & -150 & 204.9 & -1.8 & -8 & 6 & 2.4 & 1 \\
AG02 & 5.8 & -25 & 159.6 & -2.2 & -8 & 10 & -1.1 & 1 \\
AG03 & 5.4 & -24 & 159.4 & -2.1 & -7 & 10 & -5.9 & 1 \\
JAPARATUBA & 7.0 & 58 & 0.5 & -1.8 & 2 & 16 & -9.9 & 1 \\
\hline
\end{tabular}

Table 2 - Mean isotopic compositions of 0 and $\mathrm{H}$ in groundwater and surface water of the Sergipe basin (Carvalho, 2005).

\begin{tabular}{|c|c|c|c|}
\hline Well & $\begin{array}{c}\delta^{18} 0 \\
(\% 0)\end{array}$ & $\begin{array}{c}\delta^{2} \mathrm{H} \\
(\%)\end{array}$ & $\begin{array}{c}\mathrm{d} \\
(\% 0)\end{array}$ \\
\hline Oiterinhos aquifer & -4.3 & -24 & 11 \\
Maruin aquifer & -0.1 & -1 & 0 \\
Sapucari aquifer & -1.9 & -2 & 13 \\
Angico aquifer & -1.8 & -2 & 12 \\
Rivers & -0.6 & 4 & 8 \\
Lagoons & 2.6 & 18 & -3 \\
Rainwater & -0.1 & 11 & 10 \\
\hline
\end{tabular}

the excess deuterium is between 13 and $21 \%$. The increase in deuterium excess for rainwater samples may be due to the influence of re-evaporated ocean moisture in comparison to inland regions, i.e., the kinetic effects are very strong in waters under intense evaporation. In a closed system free from evaporation, the increase in deuterium excess may indicate isotopic interactions below the surface, which change $\delta^{2} \mathrm{H}$ more than $\delta^{18} 0$.

In samples from the Castanhal field, the concentrations of total dissolved salts are noticeably lower, as estimated from the electrical conductivity. Some wells have similar isotopic compositions and a deuterium excess greater than 10 , which may be the result of exchange with $\mathrm{H}_{2} \mathrm{~S}$. In nature, hydrogen sulfide originates from geological processes based on various physicochem- ical or microbiological mechanisms. When in contact with water, $\mathrm{H}_{2} \mathrm{~S}$ and water can easily exchange isotopes of hydrogen. According to Clark \& Fritz (1997), this fractionation (fractionation factor $\mathrm{a}=2.358$ ) causes the hydrogen sulfide gas to be deuteriumpoor, exchanging deuterium with ${ }^{1} \mathrm{H}$ from water. Although this fractionation is quite pronounced, a large amount of hydrogen sulfide would be required to cause considerable enrichment of a large volume of formation water.

The hypothesis of deuterium enrichment of water via exchange with $\mathrm{H}_{2} \mathrm{~S}$ is plausible due to the presence of a sulfur deposit and elevated biogeological processes in the Castanhal field. Also noteworthy is the role of sulfate reduction and formation of $\mathrm{H}_{2} \mathrm{~S}$ in the oil degradation of this field. 
The highest $\delta^{13} \mathrm{C}$ values (6.4 to $25.2 \%$ ) and DIC concentrations ( $>50 \mathrm{mM} / \mathrm{L}$ ) were found in the Castanhal and Siririzinho fields (Table 1, Fig. 4). One exception is sample CL08, which has a relatively high $\delta^{13} \mathrm{C}$ and low DIC concentration compared to other values for samples from the same field. A similar result was described by Leybourne et al. (2006) for DIC of Restigouche deposit groundwater: $\delta^{13} \mathrm{C}(\sim 12 \% 0)$ indicating carbon isotopic fractionation from methanogenesis via $\mathrm{CO}_{2}$ reduction.

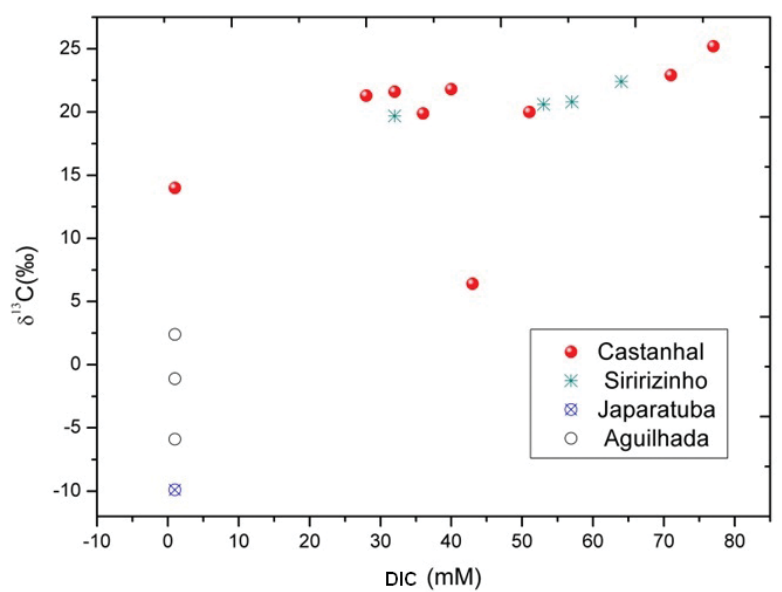

Figure 4 - Diagram of the isotopic composition of dissolved inorganic carbon concentration versus DIC.

The samples from the Aguilhada field and the water from the spring of Japaratuba have a low concentration of dissolved organic carbon $(\sim 1 \mathrm{mM} / \mathrm{L})$ and show $\delta^{13} \mathrm{C}$ in the range of -9.9 to $2.4 \%$ (Table 1). Though with low DIC concentration, the Aguilhada samples show enrichment in ${ }^{13} \mathrm{C}$ with respect to $\mathrm{CO}_{2}$ from the soil and atmosphere.

Comparison of the isotope analyses of $\delta^{13} \mathrm{C}$ and concentrations of the DIC in the selected samples (Fig. 4) shows that those most enriched in ${ }^{13} \mathrm{C}$ also have the highest DIC concentrations, which may be a strong indication for oil biodegradation.

$\delta^{13} \mathrm{C}$ in the samples varies between -9.9 and $25.2 \%$ ( Table 1) with the highest values for the samples from the Castanhal field. With the exception of sample CL08, these values are accompanied by DIC concentrations of up to $77 \mathrm{mM} / \mathrm{L}$. The elevated concentrations and isotopic enrichment of the dissolved inorganic carbon can be associated with biodegradation processes, such as methanogenesis by microorganisms, which produces methane that is strongly depleted in ${ }^{13} \mathrm{C}$ and $\mathrm{CO}_{2}$ that is enriched in ${ }^{13} \mathrm{C}$. The formation waters from the Castanhal and Siririzinho fields are extremely enriched in ${ }^{13} \mathrm{C}$ (Fig. 4) presenting one of the highest values of $\delta^{13} \mathrm{C}$ among the environmental systems.
The biodegradation of oils is commonly attributed to the activity of aerobic bacteria, which is stimulated by the introduction of surface water carrying oxygen and nutrients into oil reservoirs.

However, Da Cruz et al. (2011) studying petroleum biodegradation in deep sea reservoirs suggest that both aerobic and anaerobic bacteria usually act in consortium. Their evidences suggest that aerobic biodegradation is mainly responsible for the depletion of the linear hydrocarbons with an even-to-odd carbon preference, while anaerobic biodegradation, with odd-to-even carbon preference, was observed. They infer that mixed (aerobic and anaerobic) consortium displayed periods of $\mathrm{C}$-even preference and periods of C-odd preference, indicating the existence of alternating aerobic and anaerobic lifecycles.

In the biodegradation, the microbial metabolism of petroleum generates heavy oils, $\mathrm{CO}_{2}$, organic acids and other intermediates. In most reservoirs with low concentrations of aqueous sulfate, methanogenic degradation is a primary mechanism of petroleum degradation, whereas in waters containing abundant sulfate, sulfate reduction and sulfide production may dominate (Larter et al. 2006). The methane formed by $\mathrm{CO}_{2}$ reduction is often more depleted in ${ }^{13} \mathrm{C}$, with $\delta^{13} \mathrm{C}$ in the range of -110 to $-50 \%$. In these reservoirs, carbon dioxide, which is associated with the biodegradation of oil, is enriched in ${ }^{13} \mathrm{C}$, with $\delta^{13} \mathrm{C}$ values up to $20 \%$, indicating a closed system of $\mathrm{CO}_{2}$ reduction to methane. (Whiticar et al., 1986; Larter et al., 2006; Jones et al., 2007). Head et al. (2003) found $\delta^{13} \mathrm{C}$ values greater than $15 \%$ in $\mathrm{CO}_{2}$ generated during biodegradation. These results support the hypothesis that the positive values of $\delta^{13} \mathrm{C}$ for dissolved inorganic carbon obtained in wells in the Siririzinho and Castanhal fields are influenced by $\mathrm{CO}_{2}$ generated during the biodegradation of oils.

\section{CONCLUSIONS}

Our analyses constrain subsurface interactions of formation water in three fields of the Sergipe basin. The data distinguish samples from the Aguilhada field by their high concentration of dissolved salts and their low $\delta^{2} \mathrm{H}$ values from the other samples analyzed. The variation of $\delta^{18} 0$ values of samples is relatively small compared to the variation of $\delta^{2} \mathrm{H}$, and the more saline samples are concentrated below the GMWL.

Samples from the Castanhal field have the lowest electrical conductivities and a deuterium excess greater than 10\%, which may be the result of exchange with $\mathrm{H}_{2} \mathrm{~S}$. Some samples from this field have isotopic compositions similar to that of the local groundwater, which may indicate interaction between aquifers.

Based on the isotope analysis of dissolved inorganic carbon and its concentration in the samples analyzed, samples with 
higher ${ }^{13} \mathrm{C}$ values also have the highest concentrations of dissolved carbon, which is a strong indication of the biodegradation of oils. $\delta^{13} \mathrm{C}$ values vary between -9.9 and $25.2 \%$, and the highest values were obtained for samples from the Castanhal field.

The enrichment in the concentrations and isotope values of the dissolved inorganic carbon must be associated with biodegradation processes, such as methanogenesis, in which microorganisms generate methane that is strongly depleted in ${ }^{13} \mathrm{C}$ and $\mathrm{CO}_{2}$ that is enriched in ${ }^{13} \mathrm{C}$.

The results described here may provide important contributions in the evaluation of the biogeochemical processes occurring in oil reservoirs, furthering the knowledge of petroleum systems in exploration.

\section{ACKNOWLEDGEMENTS}

The authors thank Petrobras for funding and samples availability. We also thank the members of the UN-SE and CENPES for technical support and suggestions and contributions to the course of the work. The first author thanks CAPES for the concession of a doctoral scholarship.

\section{REFERENCES}

ANP - Agência Nacional do Petróleo, Gás Natural e Biocombustíveis. 2007. Anuário estatístico brasileiro do petróleo e do gás natural. Rio de Janeiro. 190 pp. Available on: <http://www.anp.gov.br>. Access on: May 08, 2013.

BABINSKINA \& SANTOS RCR. 1987. Origem e Classificação dos Hidrocarbonetos da Bacia Sergipe-Alagoas - Caracterização Geoquímica. Boletim de Geociências da Petrobras, 1(1): 87-95.

CAMPOS NETO OPA, LIMA WS \& CRUZ FEG. 2007. Bacia de SergipeAlagoas. Boletim de Geociências da Petrobras, 15(2): 405-415.

CARVALHO ALP. 2005. Hidrogeologia e processos cársticos nas formações Muribeca, Riachuelo e Cotinguiba na Bacia SE/AL em Sergipe. Ph.D Thesis, Institute of Geosciences, Universidade de São Paulo - USP, São Paulo, 129 pp.

CLARK I \& FRITZ P. 1997. Environmental Isotopes in Hydrology, vol. II. Lewis Press, New York. 328 pp.

CLAYTON RN, FRIEDMAN I, GRAFF DL, MAYEDA TK, MEENTS WF \& SHIMP NF. 1966. The origin of saline formation waters, 1. Isotopic composition. Journal of Geophysical Research, 71: 3869-3882.

COPLEN T \& HANSHAW B. 1973. Ultrafiltration by a compacted clay membrane-I. Oxygen and hydrogen fractionation. Geochim. Cosmochim. Acta, 37: 2295-2310.

DA CRUZ GF, DE VASCONCELLOS SP, ANGOLINI CFF, DELLAGNEZZE BM, GARCIA INS, DE OLIVEIRA VM, SANTOS NETO EV \& MARSAIOLI
AJ. 2011. Could petroleum biodegradation be a joint achievement of aerobic and anaerobic microorganisms in deep sea reservoirs? AMB Express 1: $10 \mathrm{pp}$.

GRASSI S, KOLIOS N, MUSSI M \& SARADEAS A. 1996. Groundwater circulation in the Nea Kessani low-temperature geothermal field (NE Greece). Geothermics, 25 (2): 231-247.

HEAD IM, JONES DM \& LARTER SR. 2003. Biological activity in the deep subsurface and the origin of heavy oil. Nature, 426: 344-352.

HUNT JM. 1979. Petroleum Geochemistry and Geology. W.H. Freeman and Company, San Francisco, 617 pp.

JONES DM, HEAD IM, GRAY ND, ADAMS JJ, ROWAN AK, AITKEN CM \& LARTER SR. 2007. Crude-oil biodegradation via methanogenesis in subsurface petroleum reservoirs. Nature, 451(7175): 176-180.

JUAN Y, ZHI-YUAN M, ZHAO-WEI W, WEI-LIANG L \& YAN S. 2009. Oxygen and hydrogen isotope exchange of geopressured thermal water in the central Guanzhong basin. Mining Science and Technology, 19: 115-119.

LARTER SR, HUANG H, ADAMS JJ, BENNETT B, JOKANOLA 0, OLDENBURG TBP, JONES M, HEAD I, RIEDIGER CL \& FOWLER MG. 2006. The controls on the composition of biodegraded oils in the deep subsurface. Part II - geological controls on subsurface biodegradation fluxes and constraints on reservoir-fluid property prediction. American Association of Petroleum Geologists Bulletin, 90: 921-938.

LEMAY T. 2002. Sampling of formation water from wells in the Athabasca oil sands (in situ) area, Alberta, 1999 - 2001: A compilation of protocols and methods. Alberta energy and utilities board, EUB/AGS Geo-Note 11. $40 \mathrm{pp}$.

LEYBOURNE MI, CLARK ID \& GOODFELLOW WD. 2006. Stable isotope geochemistry of ground and surface waters associated with undisturbed massive sulfide deposits; constraints on origin of waters and waterrock reactions. Chem. Geol., 231: 300-325.

MILANI EJ \& ARAÚJO LM. 2003. Recursos Minerais Energéticos: Petróleo. In: BIZZI LA, SCHOBBENHAUSC, VIDOTTIRM \& GONÇALVES JH (Eds.). Geologia, Tectônica e Recursos Minerais do Brasil. CPRM, Brasília, Brazil, 541-576.

MORAD S, WORDEN RH \& KETZER JM. 2003. Oxygen and hydrogen isotope composition of diagenetic clay minerals in sandstones: a review of the data and controlling parameters. In: WORDEN RH \& MORAD S (Eds.). Clay Mineral Cement in Sandstones. Int. Assoc. Sediment., Spec. Publ., 34: 63-91.

ORTIZ BAM. 2007. Geoquímica e isotopía de águas de formación (salmueras petroleras) de campos mesozóicos de La cuenca del Sureste de México: Implicación em su origen, evolución e interacción aguaroca em yacimientos petroleros. Ph.D. Thesis. Universidad Nacional Autónoma de México, 223 pp. 
SANTOS NETO EV. 2004. Geoquímica de gases: uma nova tecnologia em avaliação de sistemas petrolíferos. Boletim de Geociências da Petrobras, 12: 357-383.

TELES DRS, AZEVEDO AEG \& SANTOS CPL. 2010. Caracterização isotópica de águas de formação hipersalinas de um campo de petróleo da Bacia do Recôncavo, Brasil. Brazilian Journal of Geophysics,
28(2): 291-301.

WHITICAR MJ, FABER E \& SCHOELL M. 1986. Biogenic methane formation in marine and freshwater environments: $\mathrm{CO}_{2}$ reduction $\mathrm{vs}$. acetate fermentation-isotope evidence. Geochim. Cosmochim. Acta, 50: 693-709.

Recebido em 27 novembro, 2013 / Aceito em 10 julho, 2014

Received on November 27, 2013 / Accepted on July 10, 2014

\section{NOTES ABOUT THE AUTHORS}

Danilo Ribeiro de Sá Teles is physicist with Ph.D. in Geophysics by Universidade Federal da Bahia (UFBA) (2010/2014). Participated in research projects applying stable isotopes in formation water. Currently, is a substitute professor at Physics Department of Earth and Environment of the UFBA, and conducts research using stable isotopes in hydrology.

Antônio Expedito Gomes de Azevedo is graduated in Physics at Universidade de São Paulo (USP) in 1963. Received Ph.D. in Earth Sciences at Columbia University and Lamont-Doherty Earth Observatory in 1982. Currently, is a professor at Physics Institute of the Universidade Federal da Bahia (UFBA) since 1965. Research interests are stable isotopes include isotopic hydrology, carbon cycle, paleoclimatology and isotopic characterization of formation waters from petroleum fields.

Alexandre Barreto Costa is graduated in Physics from the Universidade Federal da Bahia (1997), M.Sc. and Ph.D. in Geophysics from the Universidade Federal da Bahia (2001/2006). Currently, is an assistant professor at UFBA. Has experience in Nuclear Geophysics, acting on the following topics: gamma spectrometry of sediments and rocks; radioactivity in groundwater; Carbon-14 dating; stable isotopes applied to water, organic matter and coral; and elementary analysis. In the area of geothermy, works with in the determination of radiogenic heat rocks using the technique of gamma spectrometry measurements and thermal properties of rocks.

Maria do Rosário Zucchi. is graduated in Physics from the Universidade de São Paulo (1994), master in Physics from the Universidade de São Paulo (1997) and Ph.D. in Physics from the Universidade de São Paulo (2001). Currently, is an associate professor at the Universidade Federal da Bahia. Has experience in Nuclear Geophysics, working mainly on environmental isotopes.

Alexandre de Andrade Ferreira is petroleum chemist at Petrobras Research Center (Cenpes). Received Bachelor's degree, Master's degree and Ph.D. in Chemistry from the Universidade Federal do Rio de Janeiro (1997, 2001 and 2012, respectively). Works in the organic geochemistry field with focus on the determination of stable isotopes ( $\mathrm{C}, \mathrm{H}, \mathrm{O}$ and $\mathrm{S}$ ) in natural gas, formation water, petroleum and its fractions, through either bulk measurements or compound specific isotope ratios. 